\begin{tabular}{l}
\hline $130 \quad$ Of ACCOUnting \\
Volume 1, Nomor 1, Juni 2020
\end{tabular}

\title{
Analisis Kinerja Keuangan Bank Syariah Terpilih Di Indonesia Pasca Spin Off
}

\author{
Ammar Fadil Usman', Mursalim², Muhammad Su'un ${ }^{3}$ \\ 1,2,3 Magister Akuntansi, Universitas Muslim Indonesia. \\ ${ }^{1}$ Koresponden Penulis, E-mail: ammarfadil@gmail.com
}

\begin{abstract}
ABSTRAK
Penelitian ini dilakuan untuk menganalisa kinerja keuangan Bank Syariah terpilih pasca Spin-Off menggunakan metode penilaian Risk Profile, Good Corporate Governance, Earnings, dan Capital di Indonesia. Penelitian ini menggunakan data sekunder yang diperoleh melalui dokumentasi menggunakan pendekatan kualitatif deskriptif dengan subjek penelitan yaitu Bank BNI Syariah, BCA Syariah, BRI Syariah dan Bukopin Syariah dengan rentang waktu 5 tahun pasca bank melakukan Spin-Off. Hasil penelitian ini menunjukkan bahwa: 1) Kinerja bank ditinjau dari Risk Profil menggunakan indikator NPF dimana BNI Syariah, BRI Syariah dan Bukopin Syariah tergolong sehat, sedangkan BCA Syariah tergolong sangat sehat, sedangkan indikator FDR BNI Syariah tergolong sehat, BCA Syariah tergolong sangat sehat, BRI Syariah tergolong kurang sehat, dan Bukopin Syariah tergolong cukup sehat; 2) Kinerja bank ditinjau dari GCG pada BNI Syariah tergolong sangat sehat, sedangkan BCA Syariah, BRI Syariah, dan Bukopin Syariah tergolong sehat; 3) Kinerja bank ditinjau dari Earnings menggunakan indikator ROA dimana BNI Syariah, BCA Syariah, BRI Syariah dan Bukopin Syariah tegolong cukup sehat; 4) Kinerja bank ditinjau dari Capital menggunakan indikator CAR dimana BNI Syariah, BCA Syariah, BRI Syariah dan Bukopin Syariah tegolong sangat sehat. Hal ini berarti bahwa kinerja keuangan Bank Syariah pasca Spin-Off dalam menentukan kebijakan untuk melakukan spin-off dianggap berhasil.
\end{abstract}

Kata Kunci: Kinerja Keuangan, Bank Syariah, Spin-Off, dan Metode RGEC.

\begin{abstract}
This study aims to analyze the financial performance of selected Sharia Banks after Spin-Off using the Risk Profile, Good Corporate Governance, Earnings and Capital methods in Indonesia. This research uses secondary data obtained through documentation and method is descriptive qualitative with research subjects namely BNI Syariah Bank, BCA Syariah, BRI Syariah and Bukopin Syariah with a span of 5 years after the bank conducts a Spin-Off. The results of this study indicate that: 1) Bank performance in terms of Risk Profile using NPF indicators where BNI Syariah, BRI Syariah and Bukopin Syariah are classified as healthy, BCA Syariah is very healthy, while the BNI Syariah FDR indicator is classified as healthy, BCA Syariah is very healthy, BRI Syariah is less healthy, and Bukopin Syariah is quite healthy; 2) The bank's performance in terms of GCG in BNI Syariah is classified as very healthy, while BCA Syariah, BRI Syariah, and Bukopin Syariah are healthy; 3) Bank performance in terms of Earnings using ROA indicators where BNI Syariah, BCA Syariah, BRI Syariah and Bukopin Syariah are quite healthy; 4) Bank performance in terms of Capital using CAR indicators where BNI Syariah, BCA Syariah, BRI Syariah and Bukopin Syariah are very healthy. This means that the Sharia Bank's financial performance after the SpinOff in determining the policy to conduct a spin-off is considered successful.
\end{abstract}

Keywords: Financial Performance, Islamic Banks, Spin-Offs, and RGEC Method 
Proses perkembangan keuangan Islam dapat ditelusuri hingga era Nabi Muhammad SAW. Ketika itu, doktrin mengenai operasi-operasi keuangan diperoleh langsung dari Al-Qur'an dan Sunnah, diantaranya memerinci kaidah-kaidah yang berkaitan dengan alokasi sumber daya, hak milik, produksi dan konsumsi, serta distribusi pemasukan dan kekayaan. Ellys (2015) mengatakan bahwa terdapat individuindividu yang telah melakukan fungsi perbankan di zaman Rasulullah Saw., meskipun individu tersebut tidak melakukan seluruh fungsi perbankan. Namun fungsi-fungsi utama perbankan modern, yaitu menerima simpanan uang (deposit), menyaluran dana, dan melakukan transfer dana telah menjadi bagian yang tidak terpisahkan dari kehidupan umat Islam.

Pada perkembangannya di era 1970-an, usaha-usaha untuk mendirikan bank Islam mulai menyebar ke banyak negara. Beberapa Negara seperti di Pakistan, Iran dan Sudan bahkan mengubah seluruh sistem keuangan di Negara itu menjadi sistem nirbunga, sehingga semua lembaga keuangan di negara tersebut beroperasi tanpa menggunakan bunga. Di Negara Islam lainnya seperti Malaysia dan Indonesia, bank nir-bunga beroperasi berdampingan dengan bank-bank konvensional.

Di Indonesia mayoritas penduduknya beragama Islam sehingga terciptanya inisiatif pendirian bank Islam pada tahun 1980 melalui diskusi-diskusi dan gagasan yang melahirkan Bait At-Tamwill Salman ITB di Bandung dan Koperasi Ridho Gusti di Jakarta. Tahun 1990, Majelis Ulama Indonesia (MUI) membentuk kelompok kerja untuk mendirikan Bank Islam di Indonesia yaitu PT. Bank Muamalat Indonesia. Pada tahun 1998, pemerintah dan Dewan Perwakilan Rakyat melakukan penyempurnaan UU No. 7/1992 tersebutmenjadi UU No. 10 Tahun 1998, yang secara tegas menjelaskan bahwa terdapat dua sistem dalam perbankan di tanahair (dual banking system), yaitu sistem perbankan konvensional dan sistem perbankan syariah (Antonio, 2001).

Setelah disahkannya UU No. 21 Tahun 2008, muncul trend baru pembentukan bank syariah yang implementasinya dapat dilakukan melalui dua metode pemisahan unit usaha syariah menjadi bank umum syariah (Al Arif: 2017). Pertama, bank umum konvensional yang telah memiliki UUS mengakuisisi bank yang relatif kecil kemudian mengkonversinya menjadi berbasis syariah kemudian melepaskan dan menggabungkan UUS-nya dengan bank yang baru dikonversi tersebut menjadi bank umum syariah. Kedua, bank umum konvesional melakukan pemisahan (Spin Off) terhadap UUS miliknya dan dijadikan bank umum syariah tersendiri.

Dalam UU No. 21 Tahun 2008 pasal 68 ayat 1 bahwa wajib pisah dapat dilakukan jika mencapai 50\% asset bank induknya atau 15 tahun setelah UU No. 21 Tahun 2008 setelah diperundangkan. Pada Tabel 1 menunjukkan rata-rata BOPO beberapa bank sesudah memisahkan diri (spin off) dari bank induk. Rata-rata BOPO pada tahun pertama melakukan pemisahan nilainya di atas $100 \%$, artinya pada tahun pemisahan unit usaha syariah dari bank induk konvensional akan menaikkan nilai rasio BOPO. BNI Syariah pada kuartal II tahun 2010 memiliki nilai BOPO mencapai 168,85\%, BJB Syariah memiliki BOPO mencapai 103,84\%, BRI Syariah mencapai 215,58\%, dan Bukopin Syariah mencapai 187,84\%. 
Hal tersebut menandakan bahwa sangat rendahnya tingkat efesiensi operasional bank umum syariah hasil pada periode pertama setelah pemisahan. Al Arif (2015) mengatakan bahwa naiknya nilai BOPO dipengaruhi oleh adanya tambahan biaya operasional yang selama ini ditanggung oleh bank induk konvensional kini harus ditanggung sendiri oleh bank umum syariah hasil pemisahan tersebut. Namun, pertumbuhan BOPO mengalami penurunan fluktuatif hingga pada tahun ke 2013, ini menunjukkan tingkat efisiensi operasional mengalami peningkatan.

Penilaian kinerja bank syariah tidak hanya dapat dilihat dari sisi rasio BOPOnya saja, namun ada beberapa factor penilaian yang dijadikan dasar sebagai penilaian tingkat kesehatan bank sehingga bank tersebut dapat dikatakan sehat, seperti yang di atur dalam Peraturan Otoritas Jasa Keuangan nomor 8/POJK.03/2014 tentang Penilaian Tingkat Kesehatan Bank Umum Syariah dan Unit Usaha Syariah. Cakupan penilaian tingkat kesehatan bank yang dimaksud adalah RGEC (Risk Profile, Good Corporate Governance, Earnings, dan Capital). Berdasarkan uraian latar belakang di atas, maka rumusan masalah dalam penelitian ini adalah:

1. Bagaimana kinerja keuangan Bank Syariah pasca spin-off ditinjau dari penilaian Risk Profile?

2. Bagaimana kinerja keuangan Bank Syariah pasca spin-off ditinjau dari penilaian Good Corporate Governance?

3. Bagaimana kinerja keuangan Bank Syariah pasca spin-off ditinjau dari penilaian Earnings?

4. Bagaimana kinerja keuangan Bank Syariah pasca spin-off ditinjau dari penilaian Capital?

\section{Definisi Bank Syariah}

Sutanto dan Umam (2013), mendefinisikan Bank Syariah adalah lembaga keuangan/perbankan yang operasional dan produknya dikembangkan berlandaskan Al-Quran dan hadist Nabi SAW. Menurut UU No. 21 tahun 2008 tentang perbankan syariah, Perbankan Syariah adalah segala sesuatu yang menyangkut tentang Bank Syariah dan Unit Usaha Syariah, mencakup kelembagaan, kegiatan usaha, serta cara dan proses dalam melaksanakan kegiatan usahanya.

\section{Fungsi dan Peran Bank Syariah}

Disebutkan oleh Sutanto dan Umam (2013) Dalam Pembukaan standar akuntansi yang dikeluarkan oleh AAOIFI (Accounting and Auditing Organization for Islamic Financial Institution) dijelaskan tentang fungsi dan peran bank syariah, sebagai berikut:

a) Manajer investasi, yaitu bank syariah dapat mengelola investasi dana nasabah.

b) Investor bank syariah, yaitu bank syariah dapat menginvestasikan dana nasabah yang dipercayakan kepadanya.

c) Penyedia jasa keuangan dan lalu lintas pembayaran, yaitu bank syariah dapat melakukan kegiatan jasa layanan perbankan sebagaimana lazimnya.

d) Pelaksanaan kegiatan sosial sebagai ciri yang melekat pada entitas keuangan syariah, yaitu bank islam juga memiliki kewajiban untuk mengeluarkan dan mengelola (menghimpun, mengadministrasikan dan mendistribusikan) zakat serta dana-dana sosial lainnya. 


\section{Standar Perbankan Syariah}

Aktivitas ekonomi berbasis syariah di Indonesia yang dinamis saat ini, khususnya keuangan syariah memerlukan dukungan infrastruktur seperti fatwa syariah, regulasi, dan standar akuntansi keuangan yang mencerminkan esensi aktivitas tersebut. Di Indonesia, permasalahan standarisasi laporan keuangan syariah ditangani oleh Dewan Standar Akuntansi Syariah (DSAK) yang berada di bawah naungan Ikatan Akuntan Indonesia (IAI).

Berikut beberapa Pernyataan Standar Akuntansi Keuangan (PSAK) untuk lembaga keuangan syariah :

a. PSAK 59: Akuntansi Perbankan Syariah dikeluarkan oleh Dewan Standar Akuntansi Keuangan Ikatan Akuntan Indonesia (DSAK IAI) pada 1 Mei 2002. PSAK ini terdiri dari 1-201 paragraf, sebagian pengaturan dalam PSAK 59 telah digantikan oleh PSAK 101-106 yang dikeluarkan pada 27 Juni 2007 dan PSAK 107 yang dikeluarkan pada 21 April 2009.

b. PSAK 101: Penyajian Laporan Keuangan Syariah dikeluarkan oleh DSAK IAI kemudian dialihkan kewenangannya kepada Dewan Standar Akuntansi Syariah (DSAS) IAI. PSAK 101 menggantikan pengaturan mengenai penyajian laporan keuangan syariah dalam PSAK 59 dan telah direvisi terakhir pada 25 Mei 2016.

c. PSAK 102: Akuntansi Murabahah (PSAK 102) dikeluarkan oleh Dewan Standar Akuntansi Keuangan Ikatan Akuntan Indonesia (DSAK IAI) pada 27 Juni 2007. PSAK 102 menggantikan pengaturan mengenai akuntansi murabahah dalam PSAK 59: Akuntansi Perbankan Syariah yang dikeluarkan pada 1 Mei 2002.

d. PSAK 103: Akuntansi Salam (PSAK 103) dikeluarkan oleh Dewan Standar Akuntansi Keuangan Ikatan Akuntan Indonesia (DSAK IAI) pada 27 Juni 2007. PSAK 103 menggantikan pengaturan mengenai akuntansi salam dalam PSAK 59: Akuntansi Perbankan Syariah yang dikeluarkan pada 1 Mei 2002.

e. PSAK 104: Akuntansi Istishna' (PSAK 104) dikeluarkan oleh Dewan Standar Akuntansi Keuangan Ikatan Akuntan Indonesia (DSAK IAI) pada 27 Juni 2007. PSAK 104 menggantikan pengaturan mengenai akuntansi istishna' dalam PSAK 59: Akuntansi Perbankan Syariah yang dikeluarkan pada 1 Mei 2002.

f. PSAK 105: Akuntansi Mudharabah (PSAK 105) pertama kali dikeluarkan oleh Dewan Standar Akuntansi Keuangan Ikatan Akuntan Indonesia (DSAK IAI) pada 27 Juni 2007. PSAK ini menggantikan ketentuan terkait penyajian laporan keuangan syariah dalam PSAK 59: Akuntansi Perbankan Syariah yang dikeluarkan pada 1 Mei 2002. Berdasarkan surat Dewan Pengurus Nasional (DPN) IAI No. 0823-B/DPN/IAI/XI/2013 maka seluruh produk akuntansi syariah yang sebelumnya dikeluarkan oleh DSAK IAI dialihkan kewenangannya kepada Dewan Standar Akuntansi Syariah (DSAS) IAI. Setelah pengesahan awal di tahun 2007, PSAK 105 belum ada perubahan atau revisi apapun.

g. PSAK 106: Akuntansi Musyarakah (PSAK 106) pertama kali dikeluarkan oleh Dewan Standar Akuntansi Keuangan Ikatan Akuntan Indonesia (DSAK IAI) pada 27 Juni 2007. PSAK ini menggantikan ketentuan terkait penyajian laporan keuangan syariah dalam PSAK 59: Akuntansi Perbankan Syariah yang dikeluarkan pada 1 Mei 2002. Berdasarkan surat Dewan Pengurus Nasional (DPN) IAI No. 0823-B/DPN/IAI/XI/2013 maka seluruh produk akuntansi syariah yang sebelumnya dikeluarkan oleh DSAK IAI dialihkan kewenangannya kepada 
Dewan Standar Akuntansi Syariah (DSAS) IAI. Setelah pengesahan awal di tahun 2007, PSAK 106 belum ada perubahan atau revisi apapun.

h. PSAK 107: Akuntansi Ijarah (PSAK 107) pertama kali dikeluarkan oleh Dewan Standar Akuntansi Keuangan Ikatan Akuntan Indonesia (DSAK IAI) pada 21 April 2009. PSAK ini menggantikan ketentuan terkait penyajian laporan keuangan syariah dalam PSAK 59: Akuntansi Perbankan Syariah yang dikeluarkan pada 1 Mei 2002.

\section{Konsep Spin-Off}

Raharjo (2009) mengatakan, Pemisahan (Spin off) UUS ditinjau dari UUPT dapat dibaca pada pasal 1, Pasal 135 sampai dengan Pasal 137. Pasal 1 angka 12 menyebutkan bahwa; Pemisahan adalah perbuatan hukum yang dilakukan oleh Perseroan untuk memisahkan usaha yang mengakibatkan seluruh aktiva dan pasiva perseroan beralih karena hukum kepada dua Perseroan atau lebih atau sebagai aktiva dan pasiva Perseroan beralih karena hukum kepada satu Perseroan atau lebih.

Pasal 135 ayat (1) menentukan bahwa pemisahan dapat dilakukan dengan cara pemisahan murni atau tidak murni. Pemisahan murni mengakibatkan seluruh aktiva dan pasiva Perseroan beralih karena hukum kepada 2 (dua) Perseroan lain atau lebih yang menerima peralihan dan Perseroan yang melakukan pemisahan tersebut berakhir karena hukum. Sedangkan pemisahan tidak murni mengakibatkan sebagian aktiva dan pasiva Perseroan beralih karena hukum kepada 1 (satu) Perseroan lain atau lebih yang menerima peralihan, dan Perseroan yang melakukan pemisahan tersebut tetap ada (Raharjo, 2009).

\section{Kinerja Keuangan}

Kinerja dari perusahaan atau industri profit oriented bisa diukur dengan melihat kinerja keuangan perusahaan tersebut. Semakin bagus kinerja keuangan perusahaan, maka semakin bagus pula perusahaan tersebut. Begitu pula sebaliknya, ketika kinerja keuangan sebuah perusahaan buruk, maka perusahaan tersebut dianggap tidak sehat. Apabila tidak ada penanganan yang baik terhadap perusahaan yang memiliki kinerja keuangan buruk, maka dalam waktu tertentu perusahaan tersebut akan mengalami keterpurukan sampai pada titik bangkrut atau dilikuidasi (Walisongo, 2017).

Berdasarkan PBI No. 13/1/PBI/2011 bank umum memiliki aturan baru mengenai penilaian tingkat kesehatan. Cakupan penilaiannya menggunakan pendekatan risiko dengan faktor-faktor yang dinilai antara lain Risk profile (Profil Risiko), Good Corporate Governance (GCG), Earnings (Rentabilitas), Capital (Permodalan).

\section{Penelitian Terdahulu}


Purba (2017) mengenai "Pengaruh perubahan bank umum syariah terhadap minat menabung di Bank Aceh Syariah pada masyarakat Kabupaten Aceh Tenggara", penelitian ini betujuan untuk mengetahui reaksi masyarakat dan seberapa besar pengaruh perubahan operasional bank Aceh dari sistem konvensional terhadap sistem. Dan seberapa besar pengaruh perubahan terhadap Bank Umum Islam dalam hal faktor Agama, Ekonomi dan Informasi mengenai kepentingan penyelamatan masyarakat Aceh Tenggara. Hasil penelitian menunjukkan bahwa faktor Agama dan Informasi mempengaruhi minat menabung di bank syariah Aceh sedangkan faktor ekonomi sangat berpengaruh besar terhadap kepentingan tabungan di Bank Syariah Aceh. Artinya masyarakat menilai faktor ekonomi memberi pengaruh besar padakepentingan publik untuk menabung di bank syariah (Aceh Islamic Bank).

Damanuri (2012) mengenai "Rasionalisasi konversi bank konvensional ke bank syari'ah", penelitiannya mempertanyakan system konversi yang dilakukan apakah dipengaruhi oleh factor ideologis banker dan kapitalis atau perhitungan rasional ekonomis murni? Apakah pertimbangan agama terkait dengan rasionalitas ekonomi? Jurnal ini menguraikan konversi yang digunakan tidak hanya teori pilihan, tetapi juga tindakan rasional untuk mencari kemungkinan tindakan keagamaan dengan cara yang wajar melalui perbankan syariah.

Al Arif (2017) mengenai “Metode Spin-Off dan tingkat Profitabilitas: Studi Pada Bank Umum Syariah Hasil Spin-Off”. Penelitian ini bertujuan untuk menganalisis pengaruh metode pemisahan terhadap tingkat profitabilitas. Sampel yang digunakan pada penelitian ini adalah empat bank syariah hasil pisah. Hasil penelitian menunjukkan bahwa metode pemisahan tidak berdampak pada tingkat profitabilitas di bank umum syariahhasil pemisahan, hanya tingkat efisiensi operasional (BOPO) dan tingkat pembiayaan bermasalah (NPF) yang berdampak pada tingkat profitabilitas. Hasil ini mengindikasikan bahwaunit usaha syariah yang ingin memisahkan diri dapat memilih metode pemisahan. Keputusan tergantung pada kondisi internal dari unit usaha syariah dan kebijakan internal dari bank induk konvensional.

Nasuha (2012) mengenai "Dampak Kebijakan Spin-Off terhadap Kinerja Bank Syariah". Tujuan dari kajian ini adalah untuk menemukan perbedaan kinerja keuangan dari lima bank syariah di Indonesia yaitu BNI Syariah, BRI Syariah, BJB Syariah, Bank Syariah Bukopin, dan Bank Victoria Syariah satu tahun sebelum kegiatan pemisahan (spin-off) dan satu tahun setelah kegiatan pemisahan (spin-off). Metode yang digunakan ialah tes Wilcoxon dengan menggunakan sembilan variabel yaitu aset, pembiayaan, dana pihak ketiga, pendapatan bersih, dan lima rasio keuangan (CAR, NPF, FDR, ROA, dan ROE). Hasil yang didapat menunjukkan bahwa dari empat variabel yaitu aset, pembiayaan, dana pihak ketiga, dan rasio NPF menunjukkan adanya perbedaan kinerja keuangan.

Pambuko (2019) mengenai "Kebijakan Spin-Off dan Efisiensi Perbankan Syariah di Indonesia." Studi ini bertujuan untuk menganalisis dampak kebijakan spin-off terhadap efisiensi operasional bank syariah di Indonesia. Analisis dilakukan pada 5 bank syariah yang melakukan spin-off dan efisiensi diukur dengan rasio BOPO. Variabel penelitian yang digunakan adalah dummy spin-off, ROA, FDR, dan pertumbuhan ekonomi. Analisis data menggunakan teknik regresi data panel dengan data tahunan dari 2008 hingga 2018. Hasil penelitian menemukan bahwa, 
pertama, penerapan kebijakan spin-off secara signifikan meningkatkan efisiensi operasional perbankan syariah. Kedua, ROA juga terbukti berpengaruh negatif signifikan terhadap tingkat efisiensi. Ketiga, FDR dan pertumbuhan ekonomi tidak berpengaruh signifikan terhadap efisiensi perbankan syariah di Indonesia.

\section{Kerangka Konseptual}

Seperti diketahui bahwa produk dari proses akuntansi itu adalah laporan keuangan suatu satuan usaha yang memberikan informasi tentang posisi keuangan yang bermanfaat untuk pengambilan keputusan. Hal ini adalah sesuai dengan tujuan laporan keuangan itu sendiri seperti yang dijelaskan oleh Ikatan Akuntan Indonesia dalam Standar Akuntansi Keuangan Syariah (IAI, 2016:6) bahwa “Tujuan laporan keuangan adalah menyediakan informasi yang menyangkut posisi keuangan, kinerja serta perubahan posisis keuangan suatu entitas syariah yang bermanfaat bagi sejumlah besar pengguna dalam pengambilan keputusan ekonomi".

Dengan dilakukannya spin-off badan usaha dari unit usaha syariah ke bank umum syariah maka karakteristik kinerja keuangan bank akan mengalami perbedaan dari standar pengukuran. Secara ringkas kerangka konseptual penelitian dapat digambarkan sebagai berikut :

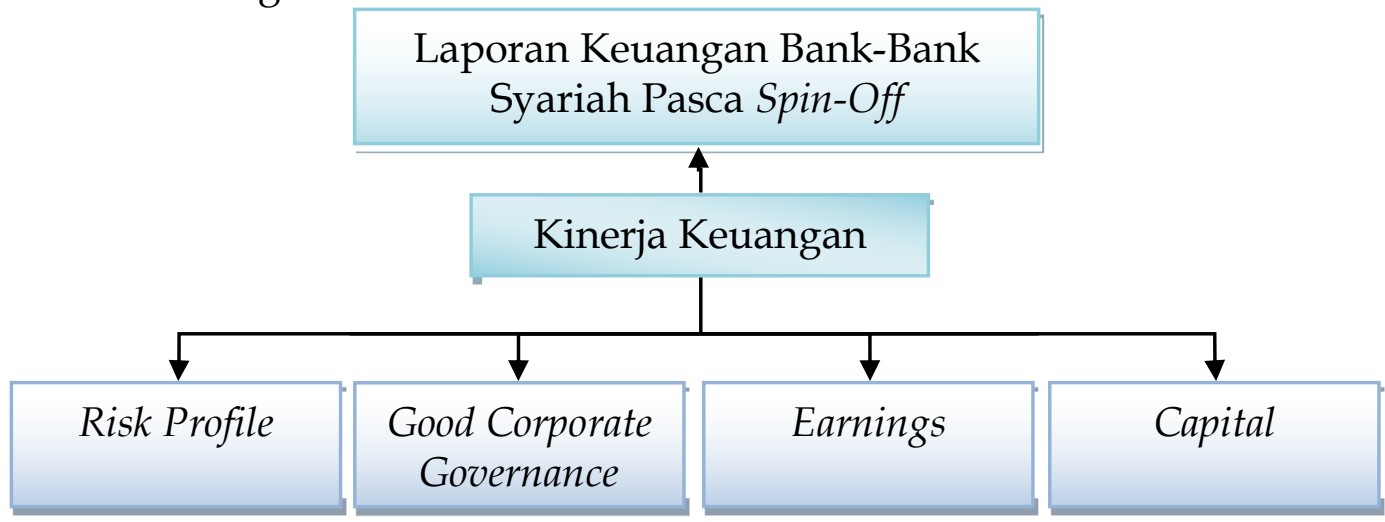

Gambar 1. Kerangka Konseptual Penelitian

Pendekatan yang digunakan dalam penelitian ini adalah pendekatan kualitatif deskriptif dengan melakukan analisis terhadap data-data Laporan Keuangan yang kemudian ditabulasikan untuk menentukan kategori bank tersebut dapat dikatakan sehat atau tidak sehat.

Metode analisis data yang digunakan dalam penelitian ini adalah Analisis Deskriptif, dimana analisis ini dilakukan dengan mengemukakan konsep teoritis dan gambaran mengenai objek penelitian serta penyajian data dari hasil penelitian. Tahapan langkah-langkah penelitian sebagai berikut :

1) Peneliti melakukan pengumpulan data berkaitan dengan penelitian

2) Menghitung rasio penelitian menggunakan metode RGEC. Rasio dalam menghitung RGEC adalah sebagai berikut:

a) Risk Profile, diwakili oleh rasio NPF (Non Performing Financing) dan FDR (Financing to Debt Ratio). 


$$
\text { NPF }=\frac{\text { Pembiayaan Bermasalah }}{\text { Total Pembiayaan }} \times 100 \% \quad \text { FDR }=\frac{\text { Total Pembiayaan }}{\text { Dana Pihak Ketiga }} \times 100 \%
$$

b) Good Corporate Governance, penilaian GCG ini diambil dari hasil Self Assessment pada laporan GCG bank syariah terkait.

c) Earnings, diwakili oleh rasio ROA (Return on Assets)

ROA $=\frac{\text { Laba sebelum Pajak }}{\text { Total Aset }} \times 100 \%$

d) Capital, diwakili oleh CAR (Capital Adequacy Ratio)

$$
\mathrm{CAR}=\frac{\text { Modal }}{\text { Aktiva Tertimbang Menurut Resiko }} \times 100 \%
$$

3) Mendeskripsikan dan menganalisis perhitungan rasio dengan metode RGEC pada tahun pertama sampai tahun kelima pasca bank spin-off. Adapun matriks kriteria penilaian tingkat kesehatan bank dengan metode RGEC secara umum ditetapkan sebagai berikut:

\begin{tabular}{|c|c|c|c|c|c|}
\hline & PK 1 & PK 2 & PK 3 & PK 4 & PK 5 \\
\hline & $\begin{array}{c}\text { Sangat } \\
\text { Sehat }\end{array}$ & Sehat & $\begin{array}{l}\text { Cukup } \\
\text { Sehat }\end{array}$ & $\begin{array}{c}\text { Kurang } \\
\text { Sehat }\end{array}$ & $\begin{array}{l}\text { Tidak } \\
\text { Sehat }\end{array}$ \\
\hline NPF & $\mathrm{NPF}<2 \%$ & $\begin{array}{c}2 \% \leq \mathrm{NPF} \\
<5 \%\end{array}$ & $\begin{array}{c}5 \% \leq \mathrm{NPF} \\
<8 \%\end{array}$ & $\begin{array}{c}8 \% \leq \mathrm{NPF} \\
<12 \%\end{array}$ & $\mathrm{NPF} \geq 12 \%$ \\
\hline$F D R$ & $\mathrm{FDR} \leq 75 \%$ & $\begin{array}{c}75 \%<\text { FDR } \\
\leq 85 \%\end{array}$ & $\begin{array}{c}85 \%<\text { FDR } \\
\leq 100 \%\end{array}$ & $\begin{array}{c}100 \%< \\
\text { FDR } \leq \\
120 \%\end{array}$ & $\begin{array}{l}\text { FDR > } \\
120 \%\end{array}$ \\
\hline$G C G$ & $\begin{array}{c}\text { Nilai } \\
\text { Komposit }< \\
1,5\end{array}$ & $\begin{array}{c}1,5 \leq \mathrm{NK}< \\
2,5\end{array}$ & $\begin{array}{c}2,5 \leq \mathrm{NK}< \\
3,5\end{array}$ & $\begin{array}{c}3,5 \leq \mathrm{NK}< \\
4,5\end{array}$ & $\begin{array}{c}4,5 \leq \mathrm{NK}< \\
5\end{array}$ \\
\hline$R O A$ & $\begin{array}{c}\mathrm{ROA}> \\
1,5 \%\end{array}$ & $\begin{array}{c}1,25 \%< \\
\mathrm{ROA} \leq \\
1,5 \%\end{array}$ & $\begin{array}{c}0,5 \%< \\
\mathrm{ROA} \leq \\
1,25 \%\end{array}$ & $\begin{array}{c}0 \%<\mathrm{ROA} \\
\leq 0,5 \%\end{array}$ & $\mathrm{ROA} \leq 0 \%$ \\
\hline$C A R$ & $\mathrm{CAR} \geq 12 \%$ & $\begin{array}{c}9 \% \leq \mathrm{CAR} \\
<12 \%\end{array}$ & $\begin{array}{c}8 \% \leq \mathrm{CAR} \\
<9 \%\end{array}$ & $\begin{array}{c}6 \%<\text { CAR } \\
<8 \%\end{array}$ & $\mathrm{CAR} \leq 6 \%$ \\
\hline
\end{tabular}

Tabel 4. Matriks Peringkat Komposit Tingkat Kesehatan Bank

\section{Sumber : Surat Edaran Bank Indonesia}

Merangkum peningkatan/penurunan kesehatan masing-masing bank syariah dengan metode RGEC.

Dalam penelitian ini, kinerja keuangan bank syariah diukur dengan pendekatan risiko (Risk-based Bank Rating) dengan menggunakan faktor RGEC (Risk Profile, GCG, Earnings, Capital) berdasarkan yang telah diatur dalam Peraturan Otoritas Jasa Keuangan No.8/POJK.03/2014 dan Surat Edaran Otoritas Jasa Keuangan No.10/SEOJK.03/2014 tentang Penilaian Tingkat Kesehatan Bank Umum Syariah dan Unit Usaha Syariah.

\section{a. Profil Resiko (Risk Profile)}

1) Non Performing Financing (NPF) 
Rasio NPF mengukur tingkat permasalahan pembiayaan yang dihadapi oleh bank. Rasio ini membandingkan pembiayaan bermasalah yaitu pembiayaan kepada pihak ketiga bukan Bank yang memiliki kualitas kurang lancar, diragukan, dan macet, dengan total pembiayaan yaitu pembiayaan kepada pihak ketiga bukan bank. Semakin tinggi rasio ini, menunjukkan kualitas pembiayaan bank syariah semakin buruk. Hasil perhitungan NonPerforming Financing bank syariah dapat tergambar dalam grafik sebagai berikut:

Gambar 2. Grafik NPF Bank Syariah Pasca Spin-Off

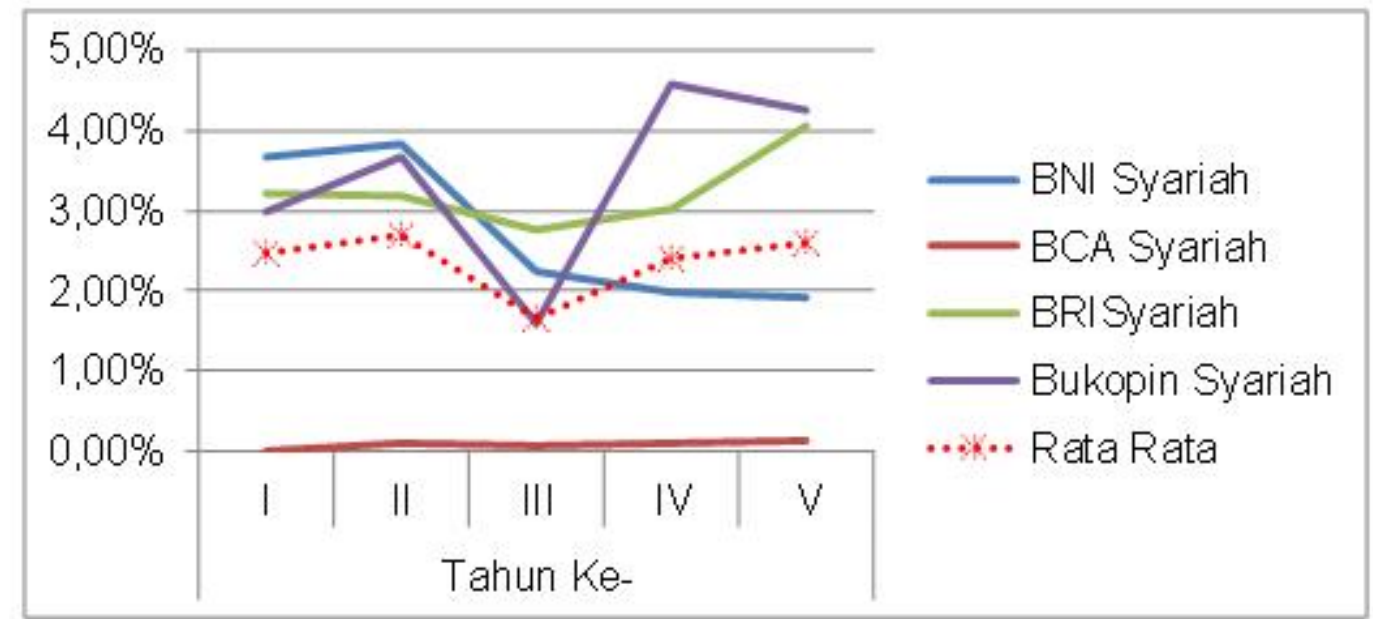

Sumber : Laporan Keuangan Tahunan (data diolah, 2019)

Berdasarkan pada tabel rasio Non Performing Financing (NPF) pada masing-masing Bank Umum Syariah yang telah melakukan spin-off yaitu Bank BNI Syariah, BRI Syariah dan Bukopin Syariah mengalami fluktuatif dari tahun pertama pasca spin-off hingga pada tahun kelima, kecuali BCA Syariah yang tetap di angka $0 \%$. Pada tahun pertama, tiga dari empat Bank Umum Syariah berada di angka 3\% yaitu, Bank BNI Syariah (3,67\%), Bank BRI Syariah (3,20\%) dan Bank Bukopin Syariah (3,00\%). Sedangkan Bank BCA Syariah sendiri berada di rasio 0,00\%. Dalam grafik 2 tergambar bahwa rata-rata rasio NPF Bank Umum Syariah tidak mengalami perbedaan yang besar ditahun pertama pasca spin-off dengan tahun-tahun setelah spin-off tersebut, dimana nilai rata-rata berada di angka 2,47\% (Sehat) ditahun pertama, 2,69\% (Sehat) ditahun kedua, 1,67\% (Sangat Sehat) ditahun ketiga, 2,42\% (Sehat) ditahun keempat dan 2,59\% (Sehat) ditahun kelima.

\section{2) Financing to Debt Ratio (FDR)}

Rasio ini digunakan untuk menilai likuiditas suatu bank dengan cara mengukur perbandingan antara jumlah pembiayaan yang diberikan oleh bank dengan dana yang diterima oleh bank. Pembiayaan yang diberikan tidak termasuk pembiayaan kepada bank lain. Dana pihak ketiga adalah seluruh dana pihak ketiga bukan bank berupa giro, tabungan, dan deposito. Hasil perhitungan Financing to Debt Ratio bank syariah dapat tergambar dalam grafik sebagai berikut: 
Gambar 3. Grafik FDR Bank Syariah Pasca Spin-Off

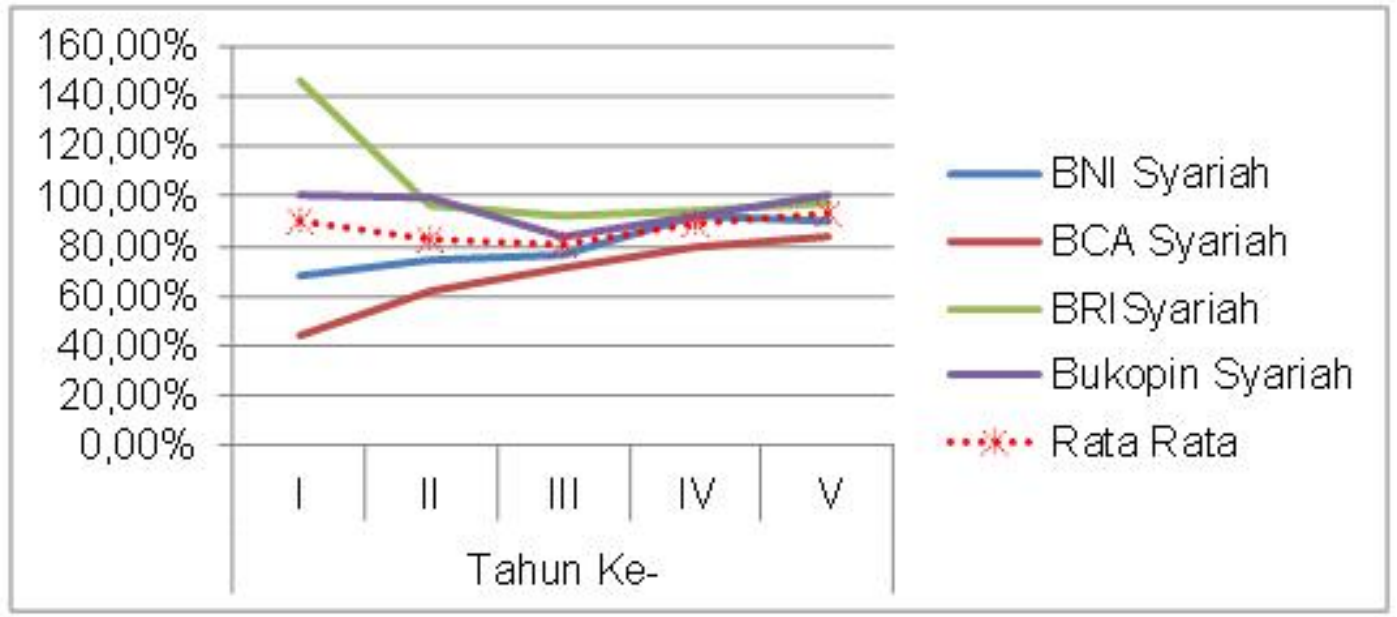

Sumber : Laporan Keuangan Tahunan (data diolah, 2019)

Berdasarkan tabel dan grafik diatas, dapat diketahui bahwa rata-rata rasio FDR bank ditahun pertama setelah melakukan spin-off tidak berada di standar yang ditetapkan oleh Bank Indonesia atau dengan kata lain bank tidak efektif dalam mengelola rasio FDRnya. Berbeda dengan bank Bukopin Syariah yang berada pada standar yang berlaku yaitu 100,35\% ditahun pertama setelah spin-off, sehingga dapat dikatakan Bank Bukopin Syariah efektif dalam mengelolah dana dan pembiayaannya. Dimana bank BNI Syariah dan BCA Syariah berada di batas bawahnya yaitu $67,87 \%$ dan 44,14\% ditahun pertama setelah spin-off, ini menunjukkan bahwa kurang efektifnya bank dalam mengelolah dana yang diterima, namun dari resiko likuiditasnya Bank BNI Syariah dan BCA Syariah sangat mampu dalam menjaga likuiditas banknya. Sedangkan Bank BRI Syariah setelah spin-off rasio FDR berada di $146,11 \%$ ini menandakan bahwa bank tidak menjaga rasio likuiditasnya sehingga semakin besar kemungkinan bank dalam kondisi bermasalah.

Ditahun kedua sampai tahun kelima, bank umum syariah yang menjadi objek penelitian setelah spin-off dapat memperbaiki kinerja rasio FDRnya dimana dapat digambarkan dalam grafik 3. Ini menandakan bahwa kinerja keuangan bank umum syariah pasca spin-off dari sisi rasio FDRnya mengalami perbedaan atau perbaikan sehingga rasio likuiditasnya cukup dan bank dalam mengelola dana dapat dikatakan efektif.

\section{b. Tata Kelola Perusahaan (Good Corporate Governance)}

Penilaian faktor Good Corporate Governance bagi Bank Umum Syariah merupakan penilaian terhadap kualitas manajemen bank atas pelaksanaan 5 (lima) prinsip Good Corporate Governance yaitu transparansi, akuntabilitas, pertanggungjawaban, profesional, dan kewajaran. Bank Umum Syariah melakukan penilaian sendiri (self assessment) pelaksanaan Good Corporate Governance secara berkala sesuai dengan periode penilaian Tingkat Kesehatan Bank. Penilaian Bank Umum Syariah telah dirangkum dalam grafik berikut: 
Gambar 4. Grafik GCG Bank Syariah Pasca Spin-Off

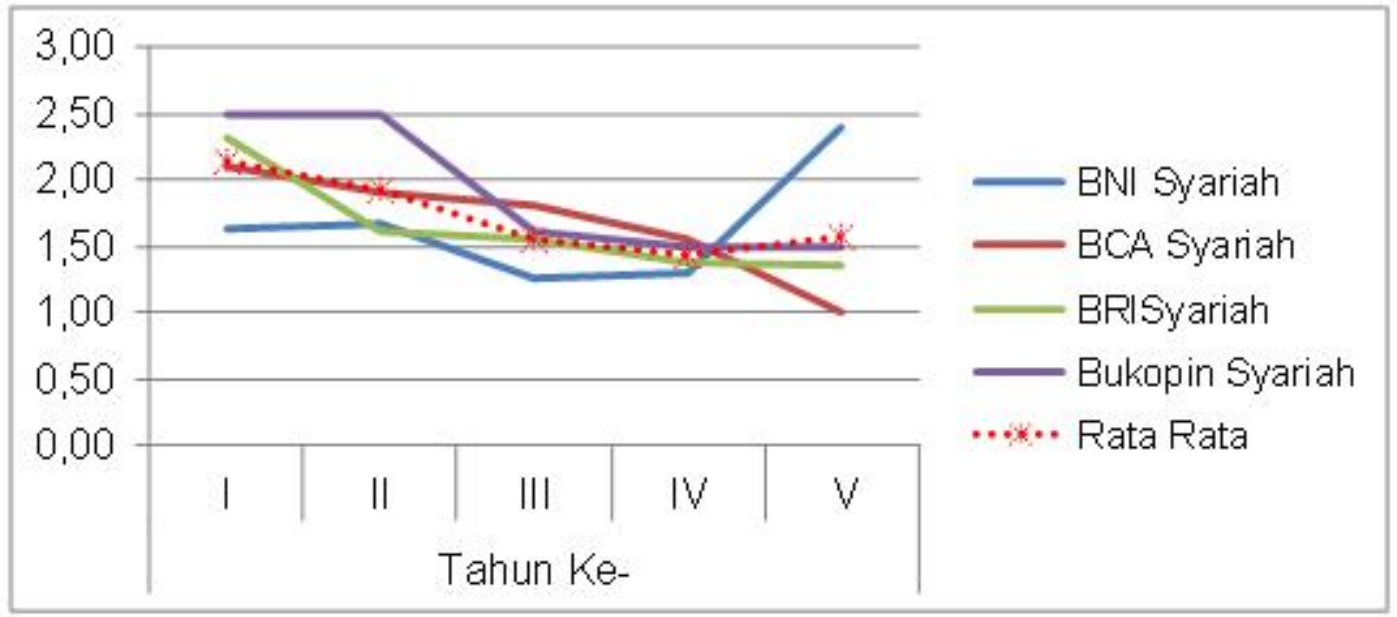

Sumber : Laporan Keuangan Tahunan (data diolah, 2019)

Berdasarkan data diatas dari pelaporan hasil penilaian self-assessment Good Corporate Governance (GCG) pada masing-masing Bank Umum Syariah yang spin-off yaitu Bank BNI Syariah, Bank BCA Syariah, Bank BRI Syariah, dan Bank Bukopin Syariah pada tahun pertama dan kedua, dari empat sampel bank syariah secara keseluruhan berada pada posisi PK-2 yakni dalam kriteria sehat. Pada periode ketiga, satu dari empat sampel bank syariah yaitu Bank BNI Syariah berada pada posisi PK-1 atau kriteria sangat sehat. Sedangkan tiga sampel lainnya yaitu BCA Syariah, BRI Syariah dan Bukopin Syariah pada penilaian tingkat GCG berada pada posisi PK-2 atau dengan kriteria sehat.

Pada periode keempat, dua dari empat sampel bank syariah yaitu BRI Syariah dan BNI Syariah pada pelaporan GCG berada pada posisi PK-1. Sedangkan dua sampel lainnya yaitu BCA Syariah dan Bukopin Syariah berada pada posisi PK-2. Pada periode kelima, dua dari empat sampel bank syariah yaitu BRI Syariah dan BCA Syariah penilaian terhadap faktor GCG berada pada posisi PK-1. Sedangan dua sampel yaitu BNI Syariah dan Bukopin Syariah dalam pelaporan self assessment GCG berada pada posisi PK-2. Secara keseluruhan dari empat sampel Bank Umum Syariah masing-masing bank syariah berada pada Penilaian Komposit yang berbedabeda.

\section{c. Rentabilitas (Earnings)}

Rasio rentabilitas adalah alat untuk menganalisis atau mengukur tingkat efisiensi usaha dan profitabilitas yang dicapai oleh bank yang bersangkutan. Penilaian faktor rentabilitas dalam penelitian ini menggunakan indikator rasio ROA (Return On Asset), rasio ini membandingkan laba sebelum pajak dengan total aset. Semakin tinggi rasio ini menandakan keberhasilan suatu bank dalam menghasilkan laba dengan mengoptimalkan aset yang dimiliki. Hasil perhitungan Return On Asset bank syariah dapat tergambar dalam grafik sebagai berikut: 
Gambar 5. Grafik ROA Bank Syariah Pasca Spin-Off

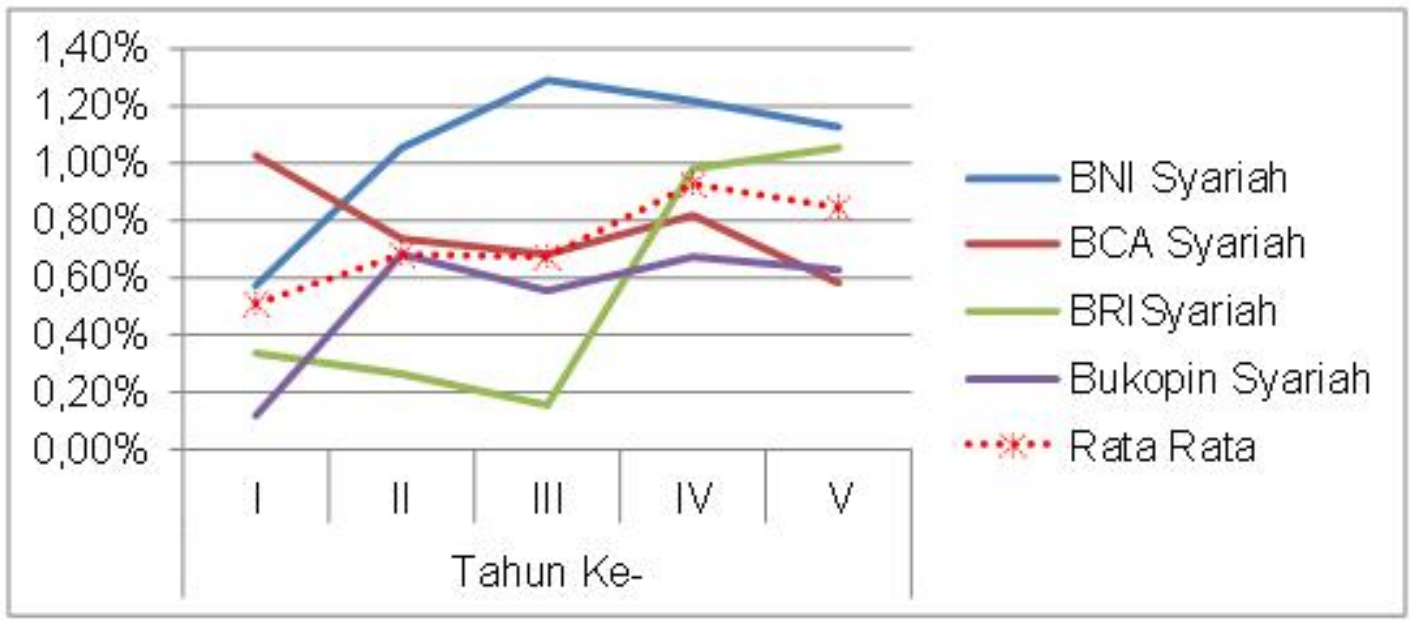

Sumber : Laporan Keuangan Tahunan (data diolah, 2019)

Berdasarkan pada grafik rasio Return On Asset (ROA) pada masing-masing Bank Umum Syariah yang telah melakukan spin-off mengalami fluktuatif dari tahun pertama pasca spin-off hingga pada tahun kelima, namun masih menunjukkan perbaikan kinerja dari tahun pertama melakukan spin-off kecuali Bank BCA Syariah yang menunjukkan kinerja buruk. Dalam grafik 5 tergambar bahwa secara rata-rata rasio ROA Bank Umum Syariah mengalami perbaikan kinerja ditahun pertama pasca spin-off dengan tahun-tahun setelah spin-off tersebut, dimana nilai rata-rata berada di angka 0,51\% (Cukup Sehat) ditahun pertama, 0,68\% (Cukup Sehat) ditahun kedua, 0,67\% (Cukup Sehat) ditahun ketiga, 0,92\% (Cukup Sehat) ditahun keempat dan 0,85\% (Cukup Sehat) ditahun kelima.

\section{d. Permodalan (Capital)}

Rasio keuangan yang digunakan dalam menilai tingkat kesehatan bank umum BUMN ditinjau dari aspek capital pada penelitian ini adalah Capital Adequacy Ratio (CAR). Rasio CAR digunakan untuk mengukur kecukupan modal yang dimiliki bank untuk menunjang aktiva yang mengandung atau menghasilkan risiko. CAR merupakan rasio perbandingan antara Modal dengan Aset Tertimbang Menurut Risiko. Rasio CAR Bank Syariah pasca spin-off dapat dilihat sebagai berikut:

Gambar 6. Grafik CAR Bank Syariah Pasca Spin-Off

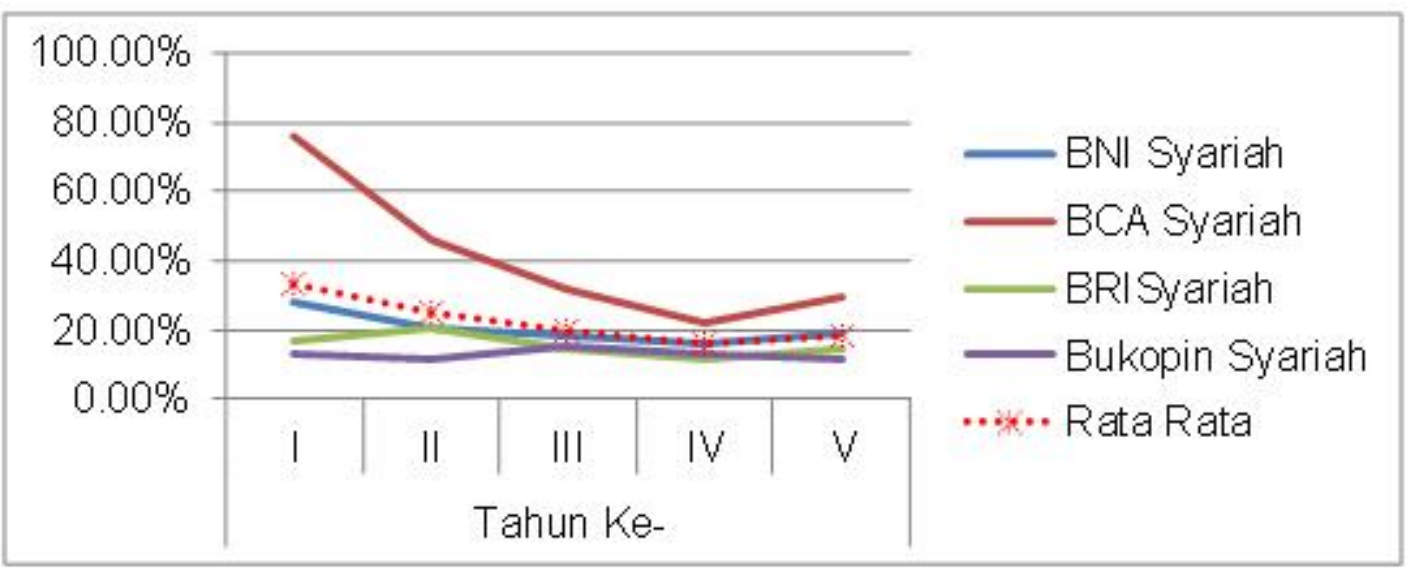


Sumber : Laporan Keuangan Tahunan (data diolah, 2019)

Berdasarkan pada grafik rasio Capital Adequacy Ratio (CAR) pada masing-masing Bank Umum Syariah yang telah melakukan spin-off mengalami penurunan kinerja dari tahun pertama pasca spin-off hingga pada tahun kelima, namun masih menunjukkan kinerja sehat. Ini diakibatkan karena peningkatan ATMR bank syariah yang sangat cepat tidak dapat diimbangi dengan penambahan modal.

Dalam grafik 6 tergambar bahwa secara rata-rata rasio CAR Bank Umum Syariah mengalami perbaikan kinerja ditahun pertama pasca spin-off dengan tahun-tahun setelah spin-off tersebut, dimana nilai rata-rata berada di angka 33,54\% (Sangat Sehat) ditahun pertama, 24,68\% (Sangat Sehat) ditahun kedua, 19,98\% (Sangat Sehat) ditahun ketiga, 15,66\% (Sangat Sehat) ditahun keempat dan 18,56\% (Sangat Sehat) ditahun kelima.

\section{KESIMPULAN}

Berdasarkan penelitian yang penulis lakukan dibeberapa bank umum syariah yaitu Bank BNI Syariah, BCA Syariah, BRI Syariah dan Bukopin Syariah mengenai kinerja keuangan pasca bank melakukan spin-off, dapat disimpulkan sebagai berikut:

1. Kinerja keungan Bank Syariah pasca spin-off ditinjau dari penilaian Risk Profile dengan menggunakan dua indikator yaitu rasio NonPerforming Financing dan rasio Financing to Debt Ratio. Untuk rasio NonPerforming Financing pada BNI Syariah, BRI Syariah dan Bukopin Syariah tergolong sehat, sedangkan BCA Syariah tergolong sangat sehat. Untuk rasio Financing to Debt Ratio pada BNI Syariah tergolong sehat, BCA Syariah tergolong sangat sehat, BRI Syariah tergolong kurang sehat, dan Bukopin Syariah tergolong cukup sehat.

2. Kinerja keuangan Bank Syariah pasca spin-off ditinjau dari penilaian Good Corporate Governance yang dilakukan dengan menggunakan self assessment pada 4 bank, yaitu BNI Syariah tergolong sangat sehat, sedangkan BCA Syariah, BRI Syariah, dan Bukopin Syariah tergolong sehat.

3. Kinerja keuangan Bank Syariah pasca spin-off ditinjau dari penilaian Earnings yang dihitung menggunakan rasio Return on Asset pada 4 bank, yaitu BNI Syariah, BCA Syariah, BRI Syariah dan Bukopin Syariah tegolong cukup sehat.

4. Kinerja keuangan Bank Syariah pasca spin-off ditinjau dari penilaian Capital yang dihitung menggunakan rasio Capital Adequacy Ratio pada 4 bank, yaitu BNI Syariah, BCA Syariah, BRI Syariah dan Bukopin Syariah tegolong sangat sehat.

5. Hasil penelitian ini menunjukkan bahwa kinerja keuangan Bank Syariah pasca spin-off dengan menggunakan metode RGEC secara umum dinilai baik, artinya kebijakan untuk melakukan spin-off ke Bank Syariah dianggap berhasil.

Al Arif, M. N. R. (2017). Metode Spinf-Off dan Tingkat Profitabilitas : Studi pada Bank Umum Syariah Hasil Spin-Off. Jurnal Kajian Ekonomi dan Bisnis Islam, Vol. 10, No. 1, Mei 2017.

Antonio, M.S. (2004). Bank Syariah Dari Teori Ke Praktik. Jakarta: Gema Insani Press. 
Bank Indonesia. (2013). Pedoman Akuntansi Perbankan Syariah Indonesia. Jakarta: Bank Indonesia

Damanuri, A. (2012). Rasionalisasi Konversi Bank Konvensional ke Bank Syari'ah. STAIN. Ponorogo

Ikatan Akuntan, I. (2016). SAK Syariah (Standar Akuntansi Keuangan Syariah). Jakarta: Dewan Standar Akuntansi Syariah.

Indonesia, R. (2008). Undang-Undang Republik Indonesia Nomor 21 Tahun 2008 tentang Perbankan Syariah Nasuha. 2012. Dampak Kebijakan Spin-Off terhadap Kinerja Bank Syariah. KARIM Business Consulting. Jakarta

Pambuko, Z.M. (2019). Kebijakan Spin-Off dan Efisiensi Perbankan Syariah di Indonesia. Universitas Muhammadiyah Magelang

Purba, A.I. (2017). Pengaruh Perubahan Bank Umum Syariah terhadap Minat Menabung di Bank Aceh Syariah pada Masyarakat Kabupaten Aceh Tenggara. Universitas Gunung Leuser.

Raharjo, H. 2009. Hukum Perusahaan. Yogyakarta: Pustaka Yustisia

Sutanto, H dan Umam, K. (2013). Manajemen Pemasaran Bank Syariah. Bandung: CV Pustaka Setia 